Research Article

\title{
CALCULATING ENERGY-INDUCED CARBON FOOTPRINT: BATMAN UNIVERSITY CASE
}

\begin{abstract}
Ali Serkan AVCI ${ }^{1}$, Hakan KARAKAYA ${ }^{2 *}$
This study determined the energy-induced carbon footprint arising from energy consumption in Batman University. It is important for universities to do acts toward control the greenhouse gas emission based on energy consumption while performing activities. Therefore, there is need to know the components of carbon footprint. Electric energy, natural gas energy, and various oils as the energy consumption components in these institutions were scrutinized. Petrol, diesel fuel, and fuel oil were utilized as types of oil. It is seen that the component which considerably specifies the carbon footprint is 3.161.238 ton $\mathrm{CO}_{2}$ value and electric energy. Natural gas and fuel oil use contribute to carbon footprint at high ratios in winter months especially arising from heating. 361 ton $\mathrm{CO}_{2}$ based on natural gas use and 1.256.445 ton $\mathrm{CO}_{2}$ based on fuel oil use are other components which specify the carbon footprint. As a result, the primary carbon footprint for Batman University was determined by IPCC Methodology and Tier 1 approach; it is 3.162.855,445 ton $\mathrm{CO}_{2}$ for 2017.
\end{abstract}

Keywords: Carbon footprint, Global climate change, Tier approach

\section{Introduction}

Greenhouse gas emission and environmental issues have emerged with the development of technology and increasing urbanization and energy consumption. Climate change based on global warming as the result of environmental issues and greenhouse gas emissions is a severe threat for our country and the world. Sustainable development, green axis growth, and environment-friendly policies become crucial in our country as well. In this regard, it is expected from organizations and people to decrease their carbon emission and increase environmental conscience.

It is observed when the literature relating to Carbon Footprint is analyzed to increase the sustainable and ecologic awareness that studies in recent years have gradually increased. Özlem reviewed some of the European countries' approaches based on power generation and consumption about carbon footprint [1]. Toröz analyzed methodology choices, calculations and results in enterprises in our

\footnotetext{
${ }^{1}$ Department of Energy Systems Engineering, University of Batman, Batman, Turkey, (aliserkan.avci@batman.edu.tr),

(D) https://orcid.org/0000-0002-0761-8642

${ }^{2}$ Department of Mechanical Engineering, University of Batman, Batman, Turkey, (hakan.karakaya@batman.edu.tr)

(iD) https://orcid.org/0000-0001-9242-6233
} 
country, the world and many European countries whose approaches on carbon footprint are different [2]. Yaka determined the carbon footprint of Health Services Vocational High School of Akdeniz University [3]. Ünald1 analyzed green marketing and carbon footprint concepts in detail [4]. Tan et al., evaluated the 30-years background of the transition process of universities in China to green and sustainable campus application [5]. Moreover, Li et al., measured the carbon footprint of students at Shanghai University in China [6].

Sangwan et al., [7] determined carbon footprint in Pilani campus of India. For their research results, indirect emissions have a $99 \%$ contribution to the footprint. Gu et al., found total energy footprint, carbon footprint and water footprint in Keele University in England [8]. They developed a conceptional correlation based on the combination of different environmental footprints to evaluate how hydrologic cycle, energy resources, climate with operations and food supply interact with each other. Ozawa-Meida et al., conducted a carbon footprint study based on consumption for a university in England [9]. Bello et al., analyzed the effects of hydroelectric consumption in Malaysia on the environment within four different frameworks as ecologic footprint, carbon footprint, water footprint, and $\mathrm{CO}_{2}$ emission [10]. Utaraskul evaluated the carbon footprint of 35 students in Rajabhat university based on three criteria. Related criteria are food consumption and energy consumption by using electrical appliances [11].

In this study, it was aimed to point out global climate change and environmental awareness by computing the carbon footprint of Batman University that is one of the institutions that produce science. Carbon footprint shows the amount of carbon dioxide and other greenhouse gas emissions that are produced as the result of daily activities. The main effects on carbon footprints include population, economic output and energy and carbon density of economy. It is significantly associated with not only the energy consumption of corporate sectors but also the consumption of industry by the increase in energy consumption. Prevalence of energy-intensive devices in houses and job environment considerably increased energy consumption. Space heating and cooling systems in buildings to provide better comfort zones increase the energy consumption in the same way.

\section{Carbon Footprint and Sustainability}

"Sustainable" and "ecologic" concepts enter into our daily life by increasing the environmental issues. "Sustainability" concept that first emerged in the international area in 1970 is defined as being provided ecological balance and protected the environment. The issue of "effect of human activities on environment" was discussed in Stockholm Conference in Switzerland in 1972; damages of related activities were highlighted [12]. It was decided to reduce the greenhouse gas emission till 2012 in Kyoto Protocol which was signed by 189 countries in 1997 Greenhouse gas emission [13]. Sustainability is a broad concept which prioritizes conservation and sustainability of natural habitat and inholds the social and economic dimensions at the same time. Sustainable development will actualize when environmental, economic and social sustainability materialize together [14].

Ecological footprint means the size of biologically fertile soil or water area in global hectares. This fertile soil or water is required to destroy the waste and reproduce the resources consumed by a community or activity via available technology and resource management [15]. The biggest share belongs to carbon footprint among the Ecological Footprint components in Turkey in 2007 [16].

Carbon footprint is composed of two parts as the primary and secondary carbon footprint. The primary carbon footprint (direct carbon footprint) is defined as the direct measurement of $\mathrm{CO}_{2}$ emissions which arise as the result of firing fossil fuels that are used for energy consumption and transportation. 
The secondary one (indirect carbon footprint) is the measurement of $\mathrm{CO}_{2}$ emissions that arise during the whole life cycle from being produced and consumed all the commodities. Carbon footprint is a crucial indicator to reveal the effects of greenhouse gas emissions on the environment and minimize those related effects.

About the Carbon Footprint Change of Turkey and the World countries, G20 countries which meet approximately $85 \%$ of the world economy and $80 \%$ of the world trade is considered. The carbon footprint of 19 state part of G20 and all the EU countries were evaluated for the period between 1990 and 2016. Figure 1 and 2 shows the carbon footprint values belong to related years on the website of World Carbon Atlas. While China, America, and India were in the leading position for carbon footprint values in 2016; Italy, France, and Argentina were in the last ranks. While America was the leading country in 1990, China reached the top in 2016. Carbon footprint values of Turkey increased approximately 2,5 times from 1990 to 2016 [17].

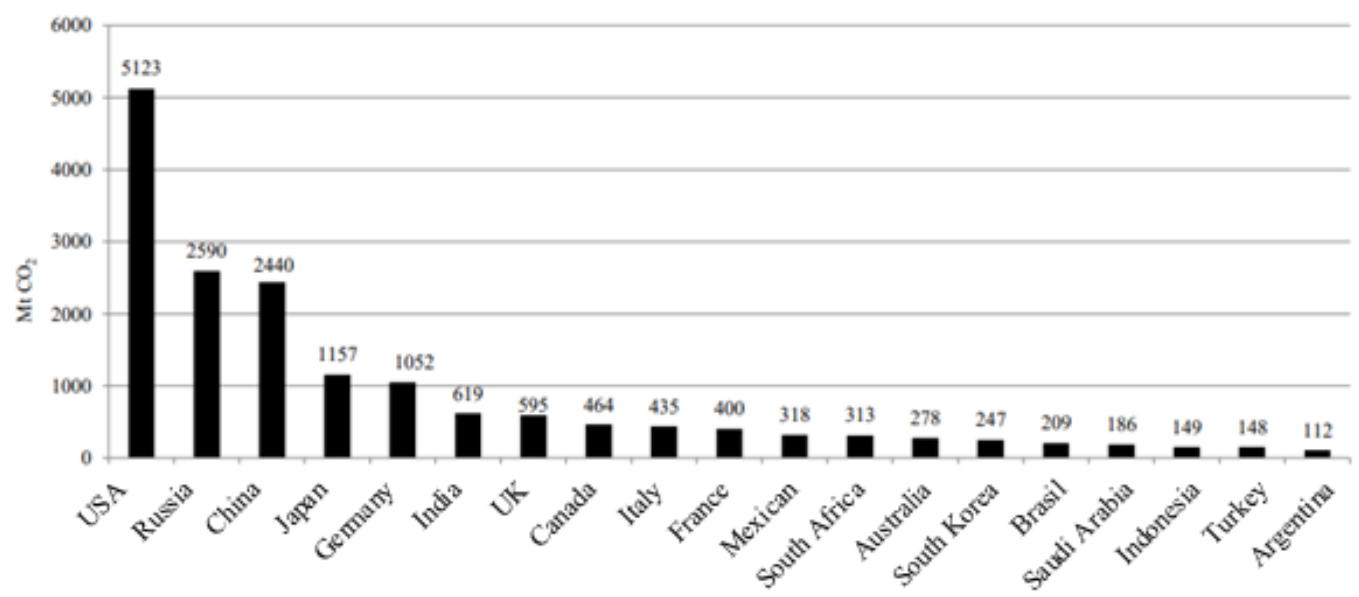

G20 Countries

Figure 1. Carbon footprint values of G20 countries in 1990 (Mt $\mathrm{CO}_{2}$ ) [18]

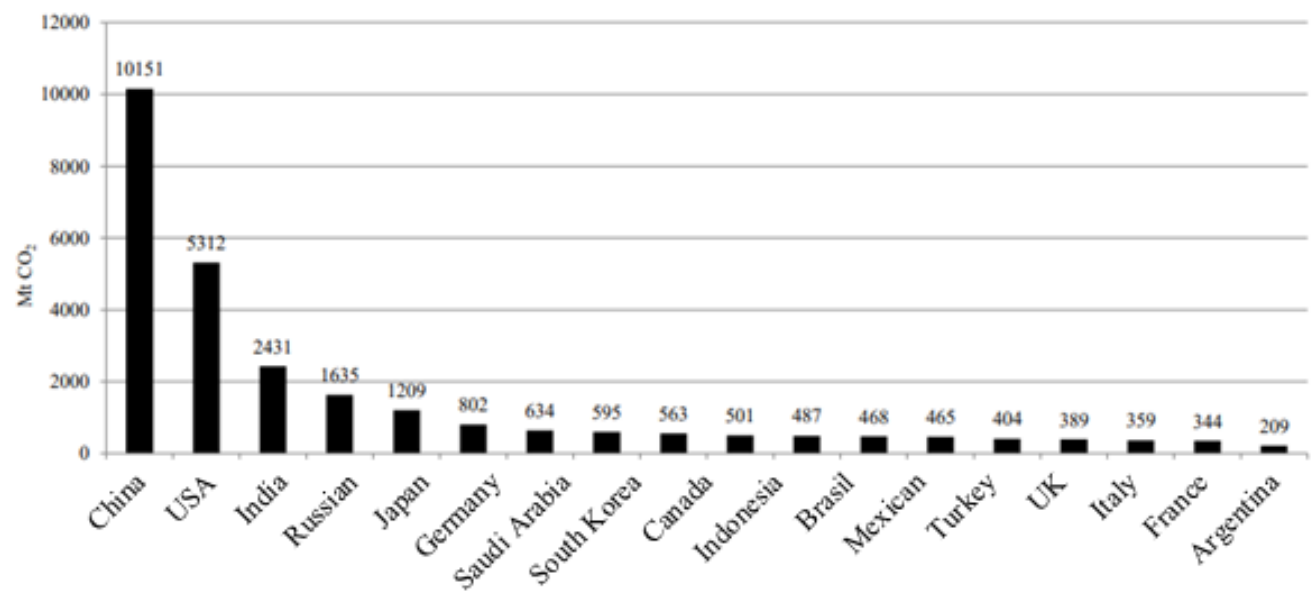

G20 Countries

Figure 2. Carbon footprint values of $\mathrm{G20}$ countries in $2016\left(\mathrm{Mt} \mathrm{CO}_{2}\right)$ [18]

Although there has been a 3 times increase in carbon footprint value of Turkey in the last 15 years, there are two main reasons for us to be at last ranks. One of the reasons is that while developed countries increased energy efficiency in other sectors which generate the emission, the yield in these 
sectors in Turkey has not increased as of yet. In other words, the share of carbon footprint in total emissions is relatively low in the transportation sector because of the high $\mathrm{CO}_{2}$ emission. The second reason is that while the mobility (number of trips per person and length of the journey) is more in developed countries, the same mobility is relatively low in developing countries such as Turkey [19].

\section{Method}

The primary carbon footprint was computed by the IPCC calculated methodology (Tier 1 approach) in this study. In this regard, carbon footprint arising from heating, transportation and electricity consumption of University was computed.

Since the carbon emission based on energy consumption of university was computed in this study, the information in energy title was utilized. 2017 Data of all departments of Batman University were analyzed. Since carbon dioxide emission is directly associated with firing the oil, it can be exactly computed. Firing conditions, technology, emission standards, and oil characteristics need to be known to compute other greenhouse gases. IPCC methodology categorized emission calculation methods at 3 different levels which are accepted as Tier [20].

Tier 1 uses the assumed emission factor in calculation; it does not consider the factors in the region where the activity is found. Resource category of each of the gas emissions and emission factor peculiar to the oil is required in the Tier 2 approach. These emission factors are specified peculiar to this country because of differences in types of oil, burning technology, working conditions, control technology, care quality and age of the equipment used for firing oil. Since the emission factor is intrinsic to country, variability and carbon dioxide emissions need to be calculated in a proper way. Tier 3 approach uses technology variable as the base and includes firing process, properties of oil and other factors that can affect calculation results $[20,21]$. This study gave the calculation method relating to the Tier 1 approach in detail; $\mathrm{CO}_{2}$ emission that has the biggest share in greenhouse gases was computed as well.

Amount of fuel consumption is determined in the calculation of carbon dioxide emissions. Gasoline, diesel, LPG, coal, natural gas and electricity consumption amounts were obtained from the official records of University. IPCC carbon dioxide emission factor, $0,584 \mathrm{ton} / \mathrm{mWh}$ that was found in master's thesis of Toröz was used to calculate carbon dioxide emission based on the electric energy [2, 20]. Energy content is computed by multiplying consumption values of fuels by transformed value in IPCC guide. Transformed values are the values in IPCC 2006 guide and the Regulation on Monitoring of Greenhouse Gas Emissions that was published in 22.07.2014 dated and 29068 numbered Official Gazette. The table shows the related values.

Table 1. Net Calorific Value of Fuels

\begin{tabular}{ll}
\hline Fuel Type & Net Calorific Value $\mathbf{( T j} / \mathbf{G g})$ \\
\hline Gasoline & 44,3 \\
Diesel & 43,0 \\
LPG (Liquefied Petroleum Gas) & 47,3 \\
Lignite Coal & 11,9 \\
Natural gas & 48,0 \\
\hline
\end{tabular}

Energy Consumption $(\mathrm{TJ})=$ Fuel Consumption $(\mathrm{t}) \times$ Net Calorific Value $(\mathrm{TJ} / \mathrm{Gg})$

At this stage, carbon emission factors in IPCC guide for each of fuel group were selected to calculate the total carbon content in the fuel. Amount of carbon content is found by multiplying carbon emission factor by the energy content value that is computed in the previous step [20]. 
Table 2. Emission Factor of Fuels

\begin{tabular}{ll}
\hline Fuel Type & Emission Factor $(\mathbf{t} \mathbf{C} / \mathbf{T j})$ \\
\hline Gasoline & 18,9 \\
Diesel & 20,2 \\
LPG (Liquefied Petroleum Gas) & 17,2 \\
Lignite Coal & 27,6 \\
Natural gas & 15,3 \\
\hline
\end{tabular}

Carbon Content $(\mathrm{t} \mathrm{C})=$ Carbon Emission Factor $(\mathrm{t} \mathrm{C} / \mathrm{TJ}) \times$ Energy Consumption $(\mathrm{TJ})$

Unoxidized carbon amount is found during firing; carbon value that completely fires is calculated. Following oxidation percentages (combustion efficiency) are specified by IPCC; 0,99 for petroleum products, 0,995 for gaseous fuels; 0,98 for coal products. The amount of oxidized carbon is computed by multiplying the carbon content by these related values.

Table 3. Oxidation Ratio of Fuels

\begin{tabular}{ll}
\hline Fuel Type & Oxidation Rate \\
\hline Gasoline & 0,99 \\
Diesel & 0,99 \\
LPG (Liquefied Petroleum Gas) & 0,99 \\
Lignite Coal & 0,98 \\
Natural gas & 0,995 \\
\hline
\end{tabular}

Carbon Emission $(\mathrm{Gg} \mathrm{C})=$ Carbon Content $(\mathrm{Gg} \mathrm{C}) \times$ Carbon Oxidation Rate

Net carbon value that is found by the proportion of the molecular weight of $\mathrm{CO}_{2}$ to the molecular weight of carbon is turned into $\mathrm{CO}_{2}$ form. At this stage, $\mathrm{CO}_{2}$ emission value is found by multiplying the previous value by $44 / 12$ that is the proportion of the molecular weight of $\mathrm{CO}_{2}$ to the molecular weight of carbon [20].

$\mathrm{CO}_{2}$ Emission $\left(\mathrm{Gg} \mathrm{CO}_{2}\right)=$ Carbon emission $(\mathrm{Gg} \mathrm{C}) \times(44 / 12)$

\section{Findings}

Data relating to electricity, gasoline, diesel, natural gas, and Fuel Oil consumption were received from university to determine the primary carbon footprint of University for 2017. Calculations were performed in line with IPCC methodology Tier 1 approach that can be seen in Method chapter. Table 4 shows the related calculations.

Tablo 4. Calculation of Carbon Footprint in Batman University

\begin{tabular}{lllllll}
\hline Energy Type & $\begin{array}{l}\text { Consumption } \\
\text { Amount } \\
\text { Year) }\end{array}$ & $\begin{array}{l}\text { Consumption } \\
\text { Amount (Ton) }\end{array}$ & $\begin{array}{l}\text { Net } \\
\text { Value } \mathbf{( T j} / \mathbf{G g})\end{array}$ & $\begin{array}{l}\text { Calorie } \\
\text { Emission } \\
\text { Factor } \\
\text { (tC / TJ) }\end{array}$ & $\begin{array}{l}\text { Carbon } \\
\text { Oxidation } \\
\text { Rate }\end{array}$ \\
\hline Gasoline & 1091 litre & 0,81 & 44,3 & 18,9 & 0,99 & 2,461 \\
Diesel & $63845 \mathrm{litre}$ & 53,6 & 43 & 20,2 & 0,99 & 170,164 \\
Natural gas & $169303 \mathrm{~m}^{3}$ & 135,44 & 48 & 15,3 & 0,995 & 361 \\
Fuel Oil & $350260 \mathrm{~kg}$ & 350,26 & 40,4 & 21,1 & 0,99 & 1083,82 \\
Electricity & $5413079 \mathrm{KWh}$ & & & & & 3161238 \\
Total & & & & & & 3162855,445 \\
\hline
\end{tabular}


Primary carbon footprint value of Batman University was found as 3.162.855,445 ton $\mathrm{CO}_{2}$ by the help of IPCC Methodology and Tier 1 approach. Electric energy is 3.161.238 ton $\mathrm{CO}_{2}$. This value is $99 \%$ of the total carbon footprint within the campus. Moreover, $0,03 \%$ of total carbon footprint results from 361 ton $\mathrm{CO}_{2}$ natural gas use and 1.256.445 ton $\mathrm{CO}_{2}$ fuel oil consumption.

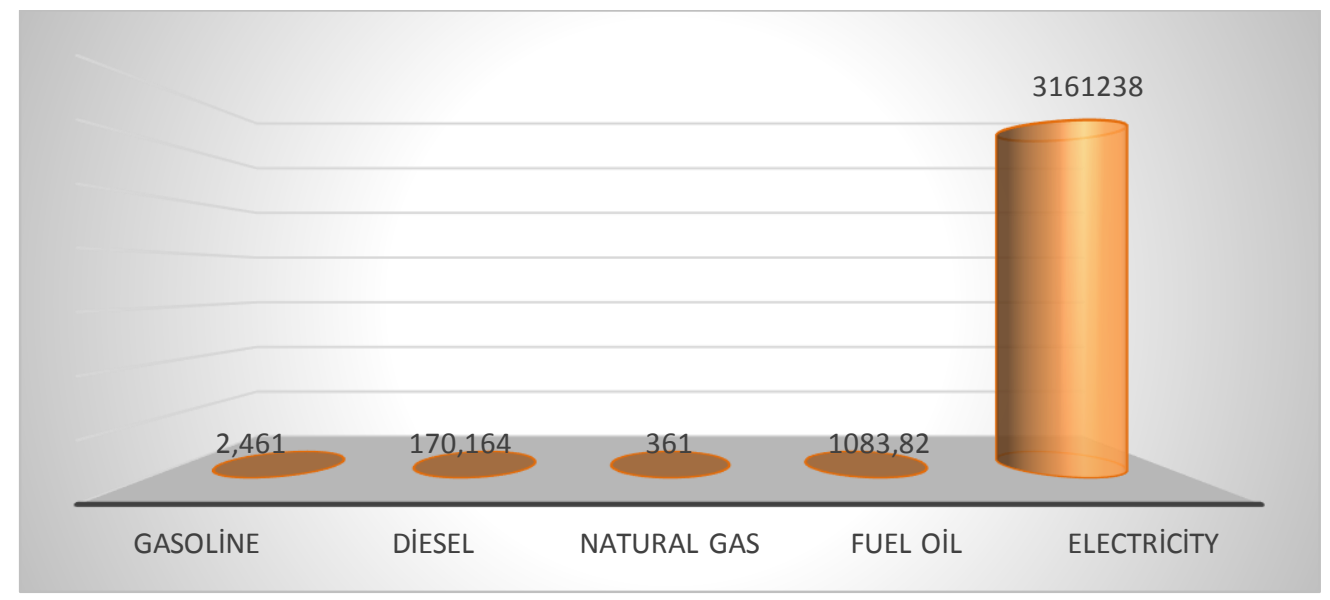

Figure 3. Batman University's Carbon Footprint ( $\mathrm{Ton}_{\mathrm{CO}}$ )

\section{Conclusion}

Need for energy gradually increases by industrialization and increasing the world population. This overconsumption brings along global climate change and increasing health risks. Due to these reasons, countries have started to reevaluate energy models. They should head for renewable energy resources that are non-depletable, clean and confidential. It is seen that renewable energy provides remarkable environmental advantages regarding greenhouse gas emissions and other classical atmosphere pollutants in comparison to classical energy systems. Turkey is extremely lucked in terms of renewable energy potential. Therefore, it is important to be effectively used available clean energy resources to avoid both environmental, social and economic problems. This study was conducted to create awareness in terms of sustainability and ecological. Greenhouse gas emissions based on energy consumption was emphasized. The primary carbon footprint is $3.162 .855,445$ ton $\mathrm{CO}_{2}$ by IPCC Methodology and Tier 1 approach for 2017 for Batman University. 99\% of this value originates in electric energy consumption. There is a need for establishing renewable power plants, notably solar power plants to meet increasing electric energy need within campus and change available energy with clean energy resource.

\section{References}

[1] Özlem, B., (2013). Seçilen Bir Kağıt Fabrikasında Karbon Ayak İzinin Belirlenmesi, Thesis, İstanbul Teknik University, 149s.

[2] Toröz, A., (2015). Gemi Kaynaklı Atıkları Alan Bir Atık Kabul Tesisinde Karbon Ayak İzinin Belirlenmesi, Thesis, İstanbul Teknik University, 135s.

[3] Yaka, İ. et al., (2015). Akdeniz Üniversitesi Sağlik Hizmetleri Meslek Yüksek Okulu Karbon Ayak İzinin Tespiti, Makine Teknolojileri Elektronik Dergisi ss. 37-45, Akdeniz University, Antalya 
[4] Ünald1, G., (2016). Yeşil Pazarlamada Karbon Ayak İzi Kavramının Değerlendirilmesi, Thesis, Hitit University, Çorum, 175s

[5] Tan, H., Chen , S., Shi, Q., ve Wang, L., (2014). Development of green campus in China, Journal of Cleaner Production, 64, 646-653.

[6] Li, X., Tan, H. ve Rackes, A., (2015). Carbon footprint analysis of student behavior for a sustainable university campus in China, Journal of Cleaner Production, 106, 97-108.

[7] Sangwan, K. S., Bhakar, V., Arora, V., \& Solanki, P. (2018). Measuring Carbon Footprint of an Indian University Using Life Cycle Assessment. Procedia CIRP, 69(1), 475-480.

[8] Gu, Y., Wang, H., Xu, J., Wang, Y., Wang, X., Robinson, Z. P., \& Zhi, X. (2019). Quantification of interlinked environmental footprints on a sustainable university campus: A nexus analysis perspective. Applied Energy, 246, 65-76.

[9] Ozawa-Meida, L., Brockway, P., Letten, K., Davies, J., \& Fleming, P. (2013). Measuring carbon performance in a UK University through a consumption-based carbon footprint: De Montfort University case study. Journal of Cleaner Production, 56, 185-198.

[10] Bello, M. O., Solarin, S. A., \& Yen, Y. Y. (2018). The impact of electricity consumption on CO 2 emission, carbon footprint, water footprint and ecological footprint: the role of hydropower in an emerging economy. Journal of environmental management, 219, 218-230.

[11] Utaraskul, T. (2015). Carbon footprint of environmental science students in Suan Sunandha Rajabhat University, Thailand. Procedia-Social and Behavioral Sciences, 197, 1156-1160.

[12] Web 1, Ozon Tabakasını incelten maddelere dair Montreal Protokolü, (1990). Link: http://iklim.cob.gov.tr/iklim/AnaSayfa/montrealptotokolu.aspx?sflang=tr, Date of Access: 19.01.2018

[13] Türkeş, M., İklim Değişikliğiyle Savaşım, Kyoto Protokolü ve Türkiye, Mülkiye Dergisi, 32, 101-131, (2014).

[14] Web 2, Engagement and the communication spectrum, (2017), Link: http://www. stepstosustainability.com, Date of Access: 20.01.2018.

[15] Özsoy Erden, C. (2015). Düşük Karbon Ekonomisi ve Türkiye'nin Karbon Ayak İzi. Emek ve Toplum, 4, 199-215.

[16] World Wide Fund for Nature(WWF)., 2012. Türkiye'nin Ekolojik Ayak İzi Raporu. 89s.

[17] Bıyık Y, (2018) Isparta İlinde Karayolu Kaynaklı Karbon Ayak İzinin Hesaplanması, Süleyman Demirel University, Thesis.

[18] Global Carbon Atlas, 2018. $\mathrm{CO}_{2}$ Emissions. Date of Access: 10.04.2018. http://www.globalcarbonatlas.org/en/content/welcome-carbon-atlas

[19] Çevre ve Şehircilik Bakanlığı (ÇŞB), 2011. Türkiye Cumhuriyeti İklim Değişikliği Eylem Planı 2011-2020. Ankara.

[20] Binboğa, G., and Aylin, Ü. N. A. L. (2018). Sürdürülebilirlik Ekseninde Manisa Celal Bayar Üniversitesi'nin Karbon Ayak İzinin Hesaplanmasına Yönelik Bir Araştırma. Uluslararası İktisadi ve İdari İncelemeler Dergisi, (21), 187-202.

[21] Turanl1, A.M. (2015). Estimation of Carbon Footprint: A Case Study for Middle East Technical University, Master of Science. (Yayımlanmamış Yüksek Lisans Tezi). Natural and Applied Sciences of Middle East Technical University, Ankara. 